\title{
SINGLE NUCLEOTIDE POLYMORPHISMS OF THE HEAT SHOCK PROTEIN 90 GENE IN VARICOCELE-ASSOCIATED INFERTILITY
}

\author{
PERICLES A. HASSUN FILHO, AGNALDO P. CEDENHO, SAMIRA B. LIMA, VALDEMAR \\ ORTIZ, MIGUEL SROUGI
}

\author{
Department of Surgery, Division of Urology, Federal University of Sao Paulo, Sao Paulo, Brazil
}

\begin{abstract}
Purpose: Varicoceles are associated with impaired testicular function and male infertility, but the molecular mechanisms by which fertility is affected have not been satisfactorily explained. Spermatogenesis might be affected by increased scrotal temperature, such as that caused by varicocele. HSP90 is a molecular chaperone expressed in germ cells and is related to spermatogenesis, motility, and both heat and oxidative stress. Possible correlations between coding single region nucleotide polymorphisms (cSNPs) in the HSP90 gene in patients with varicocele associated with infertility were analyzed, and polymorphisms in these exons were characterized through DNA sequencing.

Materials and Methods: PCR-SSCP and DNA sequencing were used to search for mutations in 18 infertile patients with varicocele, 11 patients with idiopathic infertility and 12 fertile men. DNA was extracted from leucocytes for PCR amplification and SSCP analysis. DNA from samples with an altered band pattern in the SSCP was then sequenced to search for polymorphisms.

Results: Three silent polymorphisms that do not lead to amino acid substitutions were identified.

Conclusion: Mutations in the HSP90 gene do not appear to be a common cause of male factor infertility. The low incidence of gene variation, or SNPs, in infertile men demonstrates that this gene is highly conserved and thus confirms its key role in spermatogenesis and response to heat stress.
\end{abstract}

Key words: varicocele; heat stress; Heat-Shock Protein 90; spermatozoa; infertility, genetic polymorphism

Int Braz J Urol. 2005; 31: 236-44

\section{INTRODUCTION}

The male factor is responsible for $51.2 \%$ of conjugal infertility and $39 \%$ of these men present an abnormal semen analysis for idiopathic reasons. On the other hand, varicocele is shown to be the second most common cause of male infertility leading ultimately to lower testicular volumes and important seminal alteration $(1,2)$. Despite all this evidence there is controversy as to the mechanisms by which varicocele hinders spermatogenesis and affects the fertilizing potential in men (3).

Many clinical observations suggest a link between testicular hyperthermia and reduction of sper- matogenesis by apoptosis, such as those caused by varicocele (4). However, the molecular mechanisms of gene expression affected by higher temperatures and the events that activate cell death under this condition remain unknown; these factors could be identified by specific molecular/genetic markers (5). The human genome variability may validate key evidence in understanding individual susceptibility to complex diseases. A molecular genesis for seminal alterations has been found in patients with varicocele (6), which provides new information about this disease, as well as new diagnostic possibilities.

Although some genes are expressed in both germ and somatic cells, others are exclusively ex- 
pressed in germ cells. Any disruption to the regular expression of these genes may lead to abnormal spermatogenesis (7). The highly preserved "Heat Shock Protein" (HSP) family of genes (8) is extremely important, since these genes act as molecular chaperones in a wide variety of cellular processes. HSP70 and HSP90 are expressed in germ, Sertoli and Leydig cells during the neo-natal period, and in spermatocytes and spermatids after the onset of puberty; HSP90 also expresses in spermatogonias (9). These proteins reestablish a homeostatic mechanism and equilibrium between protein synthesis and degradation in the cells (10). This has been shown in the heat-induced differential expression of HSP70 and HSP90 in varicocele $(11,12)$ and in semen cryo-preservation (13).

As well as being responsive to stress, HSP90 is a highly preserved protein that is highly abundant - between 1 and $3 \%$ of the total amount of protein found in most cells is HSP90 (14). This molecular chaperone plays an important role in spermatogenesis (15), and reduced HSP90 function in transheterozygote Drosophila sp correlates with an infertility phenotype (16). In a study conducted by Huang et al. (2000) with boar semen, the authors concluded that through direct action in these cells, HSP90 is responsible for a reduction of sperm motility (17). HSP90 is also associated with protecting the cells against oxidation damage (18).

Yue et al. (1999) suggest that a small change in HSP90 function, such as point mutations, could lead to infertility (16). It has also been reported that HSP90's role in protein folding and maturation could buffer the damaging effects of mutations (19).

In order to define the mechanisms underlying HSP90 function, Rebbe et al. (1989) determined its genomic structure, which is built of 12 exons and 11 introns (20), and as a result screening for mutations in infertile men with varicocele has become possible.

This study set out to analyze possible correlations between coding single region nucleotide polymorphisms (cSNPs) in the HSP90 gene using PCRSSCP (polymerase chain reaction - single strand conformation polymorphism) in patients with varicocele associated with azoospermia or severe oligozoospermia, and to characterize possible mutations in these exons through DNA sequencing.

\section{MATERIALS AND METHODS}

A prospective study was employed involving three groups of patients: Group A, made up of 18 infertile patients with grade II or III varicocele (14 bilateral and 4 unilateral varicoceles), of which 12 presented severe oligozoospermia $\left(<5 \times 10^{6}\right.$ sperm $\left./ \mathrm{mL}\right)$ and 6 presented azoospermia; Group B, made up of 11 patients with idiopathic infertility, of which 6 presented severe oligoasthenozoospermia and 5 presented azoospermia; and Group C, made up of 12 patients with proven fertility and without varicocele. Testicular volume was assessed in all patients through the use of a Prader orchidometer, and blood samples were collected for FSH, LH and serum testosterone dosage and for genetic analyses.

Each patient was fully informed of the objectives of this study and those that agreed with the consent form were assigned to the study. All protocols were first approved by the Research Ethics Committee.

Semen Analysis - Semen was collected twice for each patient and the samples were analyzed according to the World Health Organization guidelines (2) and sperm morphology was evaluated using strict criteria according to Kruger et al. (1996) (21).

Hormonal Analysis - A blood plasma aliquot maintained at $-20^{\circ} \mathrm{C}$ was used for luteinizing hormone ( $\mathrm{LH})$ and follicle stimulating hormone (FSH) dosage by enzyme immunoassay using the $\mathrm{IM}{ }^{\circledR}{ }_{\mathrm{x}}{ }^{\text {ystem }}$ kit from Abbott Laboratories, according to the manufacturer's protocol. Results were expressed in $\mathrm{mIU}$ hormone $/ \mathrm{mL}$ plasma. Reference values for LH and FSH are respectively 2.0 to $12.0 \mathrm{mIU} / \mathrm{mL}$ and 1.0 to $12.0 \mathrm{mIU} / \mathrm{mL}$. Another blood plasma aliquot, also maintained at $-20^{\circ} \mathrm{C}$, was tested by radioimmunoassay in solid phase to determine testosterone levels using the Coat-A-Count Total Testosterone (DPC) kit. Results were expressed in ng testosterone/dL plasma. Intra-assay variation was determined at $1.8 \%$ and inter-assay at $2.1 \%$. Reference values for 20 to 49 year old men are from 262 to $1.836 \mathrm{ng} / \mathrm{dL}$.

DNA analysis - All infertile patients were submitted to the $\mathrm{Y}$ chromosome microdeletion scan using multiplex PCR for regions AZFa, AZFb, AZFc, and AZFd. 18 pairs of oligonucleotides that are ho- 
mologous to the following STS (sequence tagged sites) were used: sY81, sY182, sY121, sYPR3, sY124 sY127, sY128, sY130, sY133, sY145, sY153, sY152, sY242, sY239, sY208, sY254, sY255, and sY157. Patients showing Y chromosome microdeletions were submitted for further analysis of chromosome abnormalities using peripheral lymphocyte culture and $\mathrm{G}$ band staining.

Based on the previously described DNA sequences for the HSP90 gene, GeneBank access J04988, primer pairs for PCR were designed from the 5' and 3' flanking regions for each of the 11 coding HSP90 gene exons (Table-1).

Purified DNA samples from leukocytes were used for the PCR reactions. Each reaction was prepared to a final volume of $50 \mu \mathrm{L}$, containing: DNA (100ng), $1.25 \mathrm{mM}$ of each deoxyribonucleotide triphosphate (dNTP), Taq DNA polymerase (2IU), 10x concentrated buffer for Taq DNA polymerase, bovine serum albumin (BSA), $2.5 \mathrm{mM}$ magnesium chloride $\left(\mathrm{MgCl}_{2}\right)$, and ultra-pure water q.s.p. The temperature cycles used in each reaction were based on previous

Table 1 - Sense and anti-sense primers used for mutation screening of the HSP9O gene.

\begin{tabular}{|c|c|c|}
\hline EXON & Primers 5' - 3' & Amplicon Size (bp) \\
\hline Exon 2 & $\begin{array}{l}\mathrm{S} \rightarrow \text { CATGGGGCCTTAGTGTTCTT } \\
\mathrm{AS} \rightarrow \text { AATGTGGAAACCAGAGCACC }\end{array}$ & 217 \\
\hline Exon 3 & $\begin{array}{l}\mathrm{S} \rightarrow \text { TTGGAAAGAGCAAAAGTAAGTTG } \\
\mathrm{AS} \rightarrow \text { TGAATGCCTACAGAACTGCAA }\end{array}$ & 270 \\
\hline Exon 4 & $\begin{array}{l}\mathrm{S} \rightarrow \text { TTGCTTCTTTAAAACTTGTGATTG } \\
\mathrm{AS} \rightarrow \text { AGCCCAGAAAATCCTAACCC }\end{array}$ & 253 \\
\hline Exon 5 & $\begin{array}{l}\mathrm{S} \rightarrow \text { AATTGCTGGTCTCAACTGCAT } \\
\mathrm{AS} \rightarrow \text { TCCTGCACGTTAAGTGTAAAAGA }\end{array}$ & 246 \\
\hline Exon 6 & $\begin{array}{l}\mathrm{S} \rightarrow \text { TCCAAGGCTAATTCTGTTTTTG } \\
\mathrm{AS} \rightarrow \text { CCATATGTGCATGTTGAGCC }\end{array}$ & 382 \\
\hline Exon 7 & $\begin{array}{l}\mathrm{S} \rightarrow \text { ATGTACCACTTATTTTTGGTTTCTTTC } \\
\mathrm{AS} \rightarrow \text { CCCAAGACTTCACCCAACTAA }\end{array}$ & 240 \\
\hline Exon 8 & $\begin{array}{l}\mathrm{S} \rightarrow \text { ACTGAGCTTTCTCACCCTGG } \\
\mathrm{AS} \rightarrow \text { GGGAATAAGCATTATTTGCCTTT }\end{array}$ & 270 \\
\hline Exon 9 & $\begin{array}{l}\mathrm{S} \rightarrow \text { TTTTTCCTCTTCCCACCCTT } \\
\mathrm{AS} \rightarrow \text { CTCCCCACTCCTCCAAAAAG }\end{array}$ & 214 \\
\hline Exon 10 & $\begin{array}{l}\mathrm{S} \rightarrow \text { TAGTCACTGAGTTCATTTAATTACCC } \\
\mathrm{AS} \rightarrow \text { AAAATATATCCTAGCCCCAGAATG }\end{array}$ & 330 \\
\hline Exon 11 & $\begin{array}{l}\mathrm{S} \rightarrow \text { TCAATCTAAGGCTTTTGTGATCG } \\
\mathrm{AS} \rightarrow \text { AAACTCCTTGCCACACCAAG }\end{array}$ & 400 \\
\hline Exon 12 & $\begin{array}{l}\mathrm{S} \rightarrow \text { TTGGTCAAGTCTCACATG } \\
\mathrm{AS} \rightarrow \text { CATCCACTTCACAAGGGA }\end{array}$ & 485 \\
\hline
\end{tabular}


annealing temperature analyses for each pair of oligonucleotides. Negative controls containing all the reagents except DNA were used in all the experiments to monitor for possible DNA contamination.

The PCR amplified DNA fragments for all 11 exons of the HSP90 gene were precipitated through addition of sodium acetate $\mathrm{pH} 6.0$ to a final concentration of $0.3 \mathrm{M}$ and absolute ethanol and further incubation at $-20^{\circ} \mathrm{C}$ for 30 minutes. After this period the tubes were centrifuged at $13,000 \mathrm{rpm}$ and the sediment was re-suspended in $20 \mu \mathrm{L}$ of TE buffer $(10 \mathrm{mM}$ Tris $\mathrm{pH} 7.4$ and 1mM EDTA). A CD buffer (05\% formamide, $0.05 \%$ xylene cyanol, $0.05 \%$ bromophenol blue and 20mM EDTA) was added to the samples, which were heated for 10 minutes prior to electrophoresis.

The PCR product was separated into a $12 \%$ polyacrilamide horizontal gel, GeneGel Excel 12.5/ 24 (Amersham Biosciences). The gel was run in a GenePhor electrophoresis chamber (Amersham Biosciences) under the following conditions: $10-15^{\circ} \mathrm{C}$, $110 \mathrm{~V}, 16 \mathrm{~mA}, 6 \mathrm{~W}$ for 20 minutes; $10-15^{\circ} \mathrm{C}, 600 \mathrm{~V}$, $42 \mathrm{~mA}, 16 \mathrm{~W}$ for 120 minutes.

DNA was observed using the PlusOne DNA Silver Staining kit (Amersham Biosciences) in the GeneStain Automated Gel Stainer automatic unit (Amersham Biosciences).

PCR products were cloned into TOPO TA Cloning Kit vectors (Invitrogen), according to the manufacturer's protocol. Sequencing reactions were performed using the Dye Primer Cycle Sequencing Ready Reaction reagent kit (Perkin Elmer) according to manufacturer's instructions. Electrophoresis was performed in the automatic ABI 377 equipment (Perkin Elmer). All PCR products were sequenced in both ways (forward and reverse), and sequencing was repeated once.

The sequences were then compared to those of the HSP90 gene found in the GeneBank database.

\section{RESULTS}

Mutation analyses were performed in the 11 coding HSP90 gene exons. Since the first exon does not codify for a protein, it wasn't evaluated. The others were analyzed (Table-1) according to the previ- ously described methodology. Seven altered conformation patterns were detected with the SSCP analysis. Figure-1 shows a polyacrilamide gel representing exon 10 of the HSP90 gene.

DNA from samples showing an abnormal band pattern on the SSCP analysis were sequenced in order to search for mutations. Three SNPs were identified: a $3774 \mathrm{C}>\mathrm{T}$ polymorphism in exon 4 of patient P11; a 6192G>A polymorphism in exon 10 of patient $\mathrm{P} 5$; and a $7602 \mathrm{G}>\mathrm{A}$ polymorphism in exon 12 of patient P8 (Figures-2, 3 and 4).

Table-2 summarizes the clinical and hormonal status of the 3 patients showing polymorphisms for the HSP90 gene, and the patient with Y chromosome microdeletions. Patient P7, who presented oligoasthenozoospermia, did not show any polymorphisms in the HSP90 gene but was tested positive for microdeletions in the AZFc and AZFd Y chromosome regions, and a raised FSH concentration $(13.0 \mathrm{mIU} /$ $\mathrm{mL}$ ). Patient $\mathrm{P} 5$ presented azoospermia and tested normal for testicular volume and hormonal levels. Patients P8 and P11 presented varicocele and were diagnosed with severe oligozoospermia, asthenozoospermia and raised FSH levels (14.5 and $16.1 \mathrm{mIU} / \mathrm{mL}$ respectively).

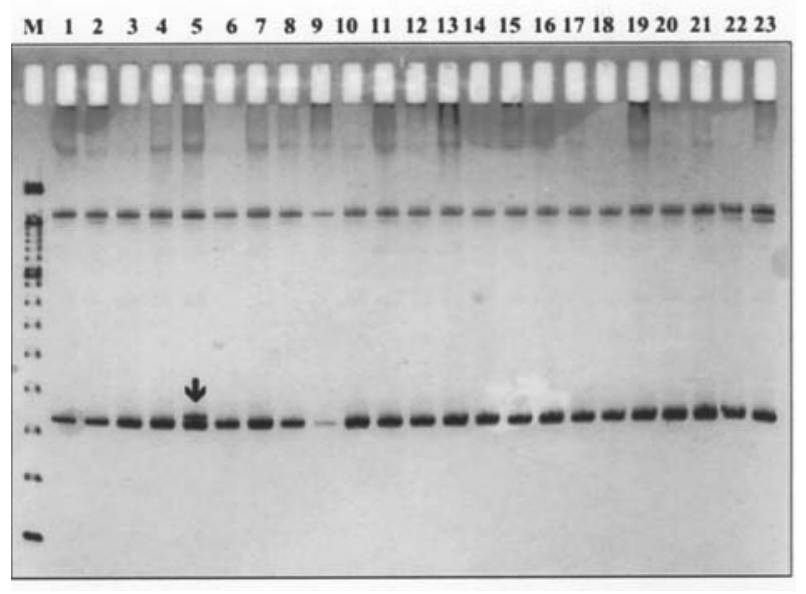

Figure 1 - Silver-stained polyacrilamide gel representing PCRSSCP band patterns for exon 10. Patients (lanes 1 to 18) and controls (lanes 19 to 23). $M=100$ bp ladder molecular marker. Lane $5(\boldsymbol{\Downarrow})$ shows patient P5 with an altered band. 

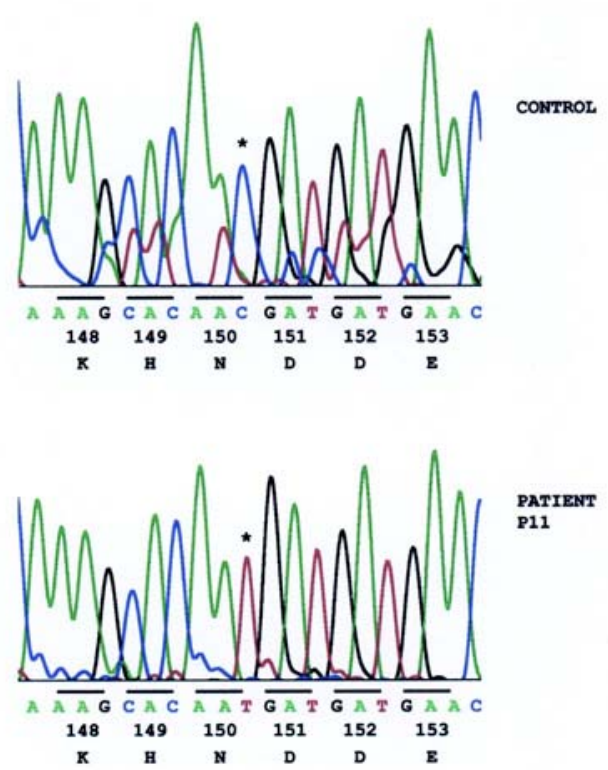

Figure 2 - Chromatograms (control and patient P11) of exon 4 of the HSP90 gene DNA sequence. (*) Indicates the 3774C>T polymorphism (AAC $\rightarrow$ AAT conversion) which codifies for
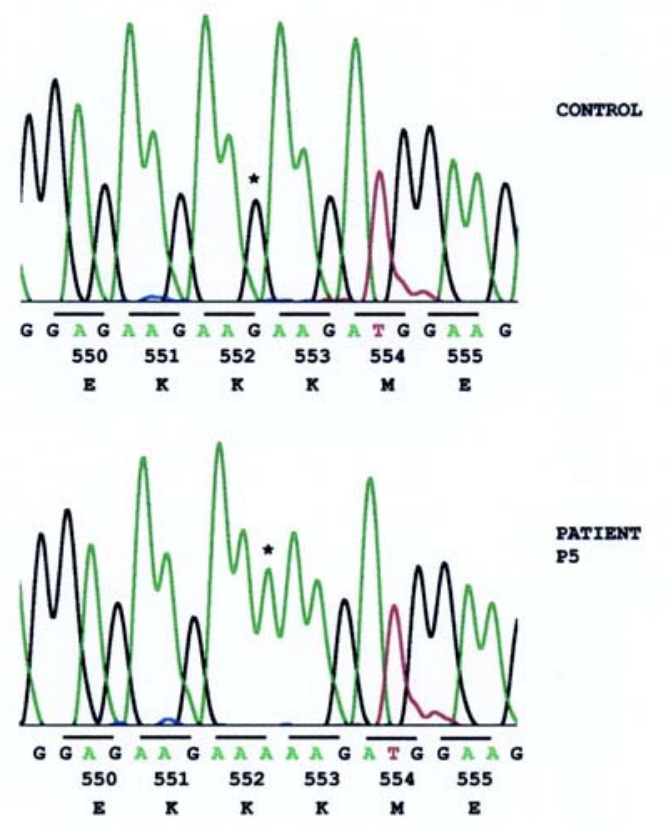

Figure 3 - Chromatograms (control and patient P5) of exon 10 of the HSP90 gene DNA sequence. (*) Indicates the $6192 G>A$ polymorphism (AA $\underline{\boldsymbol{G}} \rightarrow A A \underline{\boldsymbol{A}}$ conversion) which codifies for lysine.

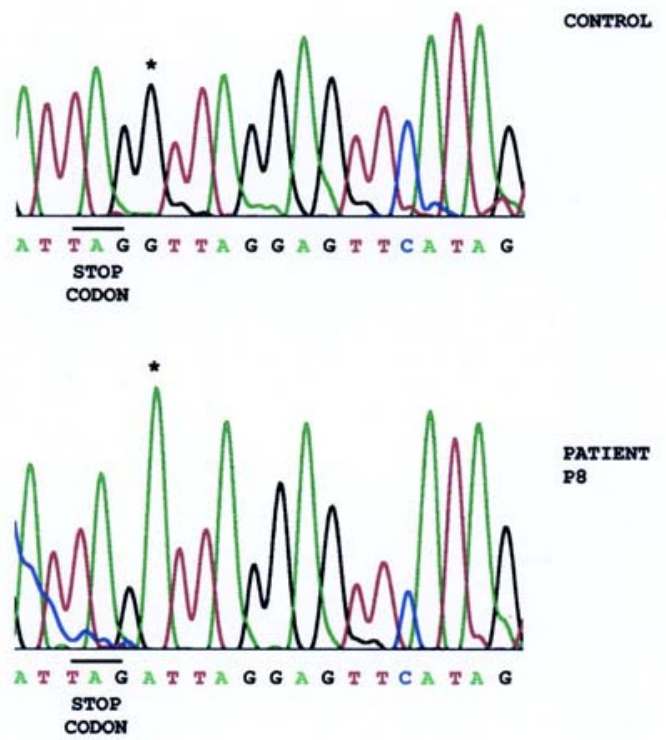

Figure 4-Chromatograms (control and patient P8) of exon 12 of the HSP90 gene DNA sequence. (*) Indicates the $7602 G>A$ polymorphism.

\section{COMMENTS}

Varicocele is one of the most frequent causes of male infertility, although the pathogenic mechanisms by which it leads to changes in spermatogenesis are not clear. Some of these mechanisms may possess a known cause, such as Y-chromosome microdeletions. In this study, the frequency of Y-chromosome microdeletions was assessed. Of the 29 patients investigated, 1 (patient P7) with severe oligozoospermia presented microdeletions in Y chromosome regions AZFc and AZFd, a frequency of $3.45 \%$, which is within the classically described range of 3$20 \%$ (22).

As well, 18 patients with azoospermia or severe oligozoospermia associated with varicocele and 11 patients with idiopathic infertility were screened for DNA polymorphisms in the HSP90 gene. Mutations in this gene could lead to oligoasthenoteratozoospermia in men similar to that shown by patients with Y chromosome microdeletions. Of all the samples analyzed, only three alterations were found, which characterizes the high conservation rate of this protein (8). Patient $\mathrm{P} 11$ possessed a $3774 \mathrm{C}>\mathrm{T}$ polymorphism in 
Table 2 - Summary of the clinical (number of spermatozoa, testicular volume and hormonal dosage) and molecular genetic status of the patients presenting with polymorphisms and/or Y-chromosome microdeletions.

\begin{tabular}{|c|c|c|c|c|c|c|c|c|}
\hline Patient & $\begin{array}{c}\text { Sperm } \\
\text { Count } \\
\left(\times 10^{6 /} / \mathrm{mL}\right)\end{array}$ & $\begin{array}{c}\text { Testicular } \\
\text { Vol. } \\
\text { (Right)/(Left) } \\
\left(\mathrm{cm}^{3}\right)\end{array}$ & $\begin{array}{c}\text { FSH } \\
(\mathbf{m I U} / \mathbf{m L})\end{array}$ & $\underset{(\mathbf{m I U} / \mathbf{m L})}{\mathbf{L H}}$ & $\begin{array}{l}\text { Testosterone } \\
(\mathrm{ng} / \mathrm{dL})\end{array}$ & Cariotype & $\begin{array}{l}\text { Y-Chromosome } \\
\text { Microdeletion }\end{array}$ & $\begin{array}{c}\text { HSP90 } \\
\text { Polymorphism }\end{array}$ \\
\hline P5 & 0 & $25 / 25$ & 1.6 & 4.4 & 329.59 & $46, X Y$ & - & $6192 G>A$ \\
\hline P7 & 0.1 & $15 / 15$ & 13.0 & 6.6 & 407.68 & $46, X Y$ & AZFc e AZFd & - \\
\hline P8 & 0.75 & $15 / 15$ & 14.5 & 6.1 & 389.27 & $46, X Y$ & - & $7602 \mathrm{G}>\mathrm{A}$ \\
\hline P11 & 0.1 & $15 / 15$ & 16.1 & 11.9 & 308.36 & $46, X Y$ & - & $3774 \mathrm{C}>\mathrm{T}$ \\
\hline
\end{tabular}

Reference values form plasmatic hormonal levels: FSH: 1.0-12.0 mIU/mL, LH: 2.0-12.0 mIU/mL, testosterone 262-1836 ng/dL.

codon 150, exon 4, which codifies for asparagine (Figure-2); Patient P5 possessed a $6192 \mathrm{G}>\mathrm{A}$ polymorphism in codon 552, exon 10, which codifies for lysine (Figure-3); and Patient P8 possessed a 7602G $>$ A polymorphism in the non-coding region (3'UTR) of exon 12, one base after the UAG stop-codon (Figure-4). Although these synonymic SNPs do not alter the protein sequence, they could lead to differences in messenger RNA (mRNA) structure and stability and affect the amount of protein produced (23).

The three SNPs found are transitions, substitutions from a purine to a purine or a pyrimidine to a pyrimidine. These alterations are sometimes originated in base incorporation errors during DNA replication. If these mutations occur in germ cells, they may be transmitted to future generations and fixate in the population. This is particularly important when genetic causes for idiopathic infertility are sought, especially in candidates for intracytoplasmic sperm injection (ICSI).

Although there is not yet any treatment to improve fertility in patients with genetic alterations, these studies have been important in male infertility diagnosis. Molecular diagnosis allows the clinician to offer adequate counseling to the patient who wishes to be a biological father, since ICSI bypasses natural selection mechanisms. Therefore, as in other areas of andrology, more basic research is needed to study varicocele etiology, especially to identify the infertility associated traits.

\section{CONCLUSION}

Mutations of the HSP90 gene do not seem to be a common cause of male factor infertility. The low incidence of gene variation or SNPs in infertile men demonstrates the high conservation rate of this gene and thus confirms its key role in spermatogenesis and response to stress.

\section{REFERENCES}

1. World Health Organization WHO: Towards more objectivity in diagnosis and management of male infertility. Results of a World Health Organization multicentre study. Int J Androl. 1987; Suppl 7, 10: 1-35.

2. World Health Organization WHO: Laboratory manual for the examination of human semen and sperm-cervical mucus interaction. $4^{\text {th }}$ ed. Cambridge University Press, 1999.

3. Schlesinger MH, Wilets IF, Nagler HM: Treatment outcome after varicocelectomy. A critical analysis. Urol Clin North Am. 1994; 21: 517-29.

4. Mieusset R, Bujan L: Testicular heating and its possible contributions to male infertility. Int J Androl. 1995; 18: 169-84.

5. Nakai A, Suzuki M, Tanabe M: Arrest of spermatogenesis in mice expressing an active heat shock transcription factor 1. EMBO J. 2000; 19: 1545-54.

6. Marmar JL: The pathophysiology of varicoceles in the light of current molecular and genetic information. Hum Reprod Update. 2001; 7: 461-72.

7. Feng HL, Sandlow JI, Sparks AE: Decreased expression of heat shock protein HSP70-2 is associated with 
the pathogenesis of male infertility. Fertil Steril. 2001; 76: 1136-9.

8. Neuer A, Spandorfer SD, Giraldo P, Dieterle S, Rosenwaks Z, Witkin SS: The role of heat shock proteins in reproduction. Hum Reprod Update. 2000; 6: 149-59.

9. Ogi S, Tanji N, Iseda T, Yokoyama M: Expression of heat shock proteins in developing and degenerating rat testes. Arch Androl. 1999; 43: 163-71.

10. Shi Y, Mosser DD, Morimoto RI: Molecular chaperones as HSF1-specific transcriptional repressors. Genes Dev. 1998; 12: 654-66.

11. Brackin P, Marmar JL, Camden NJ, Napolitano B, Millan C, Benoff S: Identification of Heat Shock Protein 70-1 (HSP70-1) in testis tissue of men with varicoceles. J Urol. 2003; 169: 415.

12. Lima SB, Hassun PA, Cenedese MA, Cedenho AP, Srougi M: Expression of the HSP70-2 gene in sperm cells of adolescents with varicocele. J Urol. 2003; 169: 452.

13. Cao WL, Wang YX, Xiang ZQ, Li Z: Cryopreservationinduced decrease in heat-shock protein 90 in human spermatozoa and its mechanism. Asian J Androl. 2003; 5: 43-6.

14. Lai BT, Chin NW, Stanek AE, Keh W, Lanks KW: Quantitation of and intracellular localization of the 85$\mathrm{k}$ heat-shock protein by using monoclonal and polyclonal antibodies. Mol Cell Biol. 1984; 4: 2802-10.

15. Gruppi CM, Zakeri ZF, Wolgemuth DJ: Stage and lineage-regulated expression of two hsp90 transcripts during mouse germ cell differentiation and embryogenesis. Mol Reprod Dev. 1991; 28: 209-17.
16. Yue L, Karr TL, Nathan DF, Swift H, Srinivasan S, Lindquist S: Genetic analysis of viable Hsp90 alleles reveals a critical role in Drosophila spermatogenesis. Genetics. 1999; 151: 1065-79.

17. Huang SY, Kuo YH, Tsou HL, Lee YP, King YT, Huang $\mathrm{HC}$, et al.: The decline of porcine sperm motility by geldanamycin, a specific inhibitor of heat-shock protein 90 (HSP90). Theriogenology. 2000; 53: 1177-84.

18. Conconi M, Szweda LI, Levine RL, Stadtman ER, Friguet B: Age-related decline of rat liver multi-catalytic proteinase activity and protection from oxidative inactivation by heat-shock protein 90. Arch Biochem Biophys. 1996; 331: 232-40.

19. Queitsch C, Sangster TA, Lindquist S: HSP90 as a capacitator of phenotypic variation. Nature. 2002; 417 : 618-24.

20. Rebbe NF, Hickman WS, Ley TJ, Stafford DW, Hickman S: Nucleotide sequence and regulation of a human 90-kDa heat shock protein gene. J Biol Chem. 1989; 264: 15006-11.

21. Kruger TF, Lacquet FA, Sarmiento CA, Menkveld R, Ozgur K, Lombard, CJ, et al.: A prospective study on the predictive value of normal sperm morphology as evaluated by computer (IVOS). Fertil Steril. 1996;66: 285-91.

22. Maurer B, Gromoll J, Simoni M, Nieschlag E: Prevalence of Y chromosome microdeletions in infertile men who consulted a tertiary care medical center: the Munster experience. Andrologia. 2001; 33: 27-33.

23. Kwok PY, Gu Z: Single nucleotide polymorphism libraries: why and how are we building them? Mol Med Today. 1999; 5: 538-43.

\footnotetext{
Correspondence address:

Dr. Péricles Assad Hassun Filho

R. Leandro Dupret, 204 / 43

São Paulo, SP, 04025-010, Brazil

Fax: + 5511 5575-9077

E-mail:pericles.hassun@gmail.com
} 


\section{EDITORIAL COMMENT}

\section{VARICOCELES, HEAT AND HEAT SHOCK PROTEINS - THAT IS THE QUESTION!}

The variable effect of the varicocele on spermatogenesis remains enigmatic. Why do varicoceles affect spermatogenesis? Why not all patients with varicoceles have abnormal spermatogenesis? An understanding of the pathophysiology of the varicocele will allow patients and their physicians to choose the most appropriate therapy for their infertility and varicocele.

In the current article by Hassun Filho et al., the molecular basis of varicocele associated abnormal spermatogenesis is explored.

The authors studied single nucleotide polymorphisms of the heat shock protein (HSP) 90 gene in men with varicocele associated infertility. Heat-shock proteins are molecular chaperones, which assist other proteins in their folding, transport and assembly into complexes, thus protecting both protein structure and function. These heat shock proteins are most often induced by physiological stress such as heat (heat shock protein) and other stresses. Heat shock proteins are classified according to their molecular weight: HSP25, HSP47, HSP60, HSP70/ 72, HSP90, and HSP110 (1). Thus, their expression in the testicle protects the germ cells from environmental hazards such as heat, radiation, and chemicals (2). The activation of this genetically programmed response to stress has been evolutionary conserved (3). Thus, suggesting that mutations affecting HSP90 could theoretically lead to infertility (4). Therefore, such mutations could limit the protective effects of heat shock protein in response to the stress induced by varicoceles.

Some have suggested that HSP dysregulation in varicocele patients initiates germ cell apoptosis, and, it follows that coding and noncoding mutations could interfere with the normal protein kinetics of HSP90 (5). Simsek et al. documented increased apoptosis in patients with varicoceles (6).

Other attempts have been made to explain the variable impact of the varicocele on spermatoge- nesis. Nagler and coworkers constructed the The Cofactor Hypothesis of the varicocele in 1990 (7). This hypothesis states that, perhaps, the varicocele is a cofactor, which allows other gondatoxins to manifest themselves. This work demonstrated that nicotines' effect on spermatogenesis was more pronounced when administered in conjunction with an experimental varicocele. Marmar \& Benoff subsequently proposed a "two hit hypotheses" (8). This hypothesis states that molecular or genetic defects may be required for the varicocele to exert its deleterious effects on spermatogenesis. In the absence of such defects, men with varicoceles may be fertile. It is this later hypothesis that is studied in the current manuscript.

The current study, unfortunately, does not allow us to conclude that mutations in the HSP cascade are the underlying pathophysiologic mechanism of the abnormal spermatogenesis associated with the varicocele. The assessment of Y chromosome microdeletions although, as the authors note, is consistent with published data for infertile men does not relate to the varicocele. If mutations in HSP were identified in the men with varicoceles and infertility, it would perhaps provide evidence that disruption in this highly conserved protective mechanism could explain the variable impact of the varicocele on spermatogenesis. Nevertheless, there is little doubt the genetic/molecular studies of infertility will ultimately provide additional understanding. Alas, no differences in the HSP genes were observed in this small population. Thus, we are, again left questioning why does a varicocele affect spermatogenesis when it does and why does not the varicocele always affect spermatogenesis.

\section{REFERENCES}

1. Morimoto RI, Tissieres A, Georgopoulos C: Progress and Perspectives on the Biology of Heat Shock Proteins and Molecular Chaperones. Cold Spring Harbor, Cold Spring Harbor Press, 1994. 
2. Legare C, Thabet M, Sullivan R: Expression of heat shock protein 70 in normal and cryptorchid human excurrent duct. Mol Hum Reprod. 2004; 10: 197-202.

3. Feder ME, Hofmann GE: Heat-shock proteins, molecular chaperones, and the stress response: Evolutionary and ecological physiology. Annu Rev Physiol. 1999; 61: 243-82.

4. Yue L, Karr TL, Nathan DF, Swift H, Srinivasan S, Lindquist S: Genetic analysis of viable Hsp90 alleles reveals a critical role in Drosophila spermatogenesis. Genetics. 1999; 151: 1065-79.

5. Lue YH, Hikim AP, Swerdloff RS, Im P, Taing KS,
Bui T, et al.: Single exposure to heat induces stagespecific germ cell apoptosis in rats: role of intratesticular testosterone on stage specificity. Endocrinology. 1999: 140: 1709-17.

6. Simsek F, Turkeri L, Cevik I, Bircan K, Akdas A: Role of apoptosis in testicular damage caused by varicocele. Arc Esp Urol. 1998; 51: 947-50.

7. Peng BC, Tomashefsky P, Nagler HM: The cofactor effect: varicocele and infertility. Fertil Steril. 1990; 54 : 143-8.

8. Marmar J, Benoff S: New scientific information related to varicoceles. J Urol. 2003; 170 (6 pt 1): 2371-3.

Dr. Harris M. Nagler Beth Israel Medical Center and Albert Einstein College of Medicine New York, New York, USA 